\title{
Grunto, armuoto geotinklais, kerpamojo stiprio tyrimai
}

Šarūnas Skuodis,

Neringa Dirgèlienè

Vilniaus Gedimino technikos universitetas, Statybos fakultetas,

Gelžbetoniniu konstrukciju

ir geotechnikos katedra,

Sauletekio al. 11,

10223 Vilnius, Lietuva

El.paštas sarunas.skuodis@vgtu.lt
Skuodis Š., Dirgèlienė N. Grunto, armuoto geotinklais, kerpamojo stiprio tyrimai. Geologija. Geografija. 2018. T. 4(2). ISSN 2351-7549.

Straipsnyje apžvelgtos grunto kerpamojo stiprio savybès, kai gruntui armuoti yra naudojami geotinklai. Pastaruoju metu šis metodas Lietuvoje yra plačiai taikomas statybų srityje, tiesiant kelius ir geležinkelius. Triašio slègio bandymuose tirti vieni iš dažniausiai grunto armavime naudojamų lanksčių ir standžių geotinklų, kurių stipris tempiant išilgai ir skersai $\geq 40 \mathrm{kN} / \mathrm{m}$. Gauti pikinių ir liekamụjų kerpamojo stiprio rezultatai palyginti su nearmuoto grunto, atliktas palyginimas tarp standžiais ir lanksčiais geotinklais armuotų bandinių. Nustatyta, kad geotinklų naudojimas armuojant grunto kompozitines konstrukcijas pagerina armuotų konstrukcijų savybes, palyginti su nearmuotomis.

Raktažodžiai: geotinklai, smèlis, kerpamasis stipris, vidinès trinties kampas, sankiba

\section{IVADAS}

Visi inžineriniai statiniai vienaip ar kitaip yra susiję su gruntais. Statiniai negali egzistuoti be pamatų, per kuriuos i grunto masyvą yra perduodamos apkrovos, arba asfalto danga negali būti kokybiška, jei grunto konstrukcija, esanti po danga, yra prastos kokybès ir t. t. Esant palankioms sąlygoms, kai gruntai pasižymi pakankamai geromis fizinemis ir mechaninèmis savybėmis, masyvas sudarytas iš natūraliai slūgsančių gruntų gali perimti inžinerinių statinių apkrovas ir nesuirti arba nesideformuoti daugiau nei leidžia statybos techniniai reglamentai. Grunto deformacijos ypač aktualios statant ir eksploatuojant automobilių kelius bei geležinkelius. Dažnai tinkamo pagrindo viršutinis sluoksnis yra iš technogeninio piltinio grunto, kuris perima apkrovas. Priklausomai nuo natūralių gruntų savybių ir pagrindus veikiančių apkrovų, technogeninių gruntų sluoksniai papildomai gali būti armuojami geotinklais. Taip pat norint padidinti keliuose naudojamų grunto konstrukcijų laikomąsias gebas bei sumažinti ir suvienodinti nuosẻdžius naudojami geotinklai, kurie paverčia grunto konstrukcijas i kompozitines grunto konstrukcijas.

Šiuo metu rinkoje egzistuoja du geotinklų tipai: lankstūs ir standūs. Abu šie tipai gali būti plačiai naudojami kompozitinèse grunto konstrukcijose, nes iš esmès tai yra praktiškai vienodi ir lygiaverčiai gaminiai. Geotinklai gali būti gaminami keliais skirtingais būdais (ekstruziniu, austiniu, virinimo ir kt.) bei iš skirtingos sudèties medžiagų (polietileno, polipropileno ir kt.). Nepaisant geotinklų gaminimo būdų bei skirtingos gaminio medžiagų sudèties, visi gamintojai nurodo geotinklu savybes.

Viena iš svarbiausių geotinklų savybių yra stipris tempiant skersai ir išilgai. Atskirai pateikiamos stiprio vertès esant skirtingiems pailgejimams, pavyzdžiui, Lietuvoje armavimui naudojamų geotinklų gaminių projektinis stipris nustatomas esant $1 \%$, $2 \%, 5 \%$ ir $10 \%$ pailgèjimui veikiant apkrovai. Jei pailgèjimas esant didžiausiai apkrovai yra didesnis nei $10 \%$, būtina pateikti tipinę jejgos ir deformacijos kreivę (Geosintetikos naudojimo..., 2013). 
Projektinis stipris prie skirtingų pailgèjimų yra nustatomas eksperimentiškai, t. y. tempiant geotinklą ir matuojant deformacijas bei apkrovas. Pažymètina, kad toks bandymas yra atliekamas be grunto, t. y. geotinklas neturi kontakto su būsimu gruntu, kuris yra numatytas projekte, bei nèra vertinama būsima grunto kompozitinès konstrukcijos eksploatacinė apkrova. Vertinant geotinklų armavimo ittaką grunto kompozitinèse konstrukcijose, visos kitos geotinklų savybès (medžiaga, svoris ploto vienetui, pagaminimo būdas, gaminio medžiaga, akutès dydis, rulono matmenys, spalva, paviršiaus šiurkštumas ir pan.), kurios yra pateikiamos gaminio techninèje specifikacijoje, yra nereikšmingos (Geosintetikos naudojimo..., 2013).

Apskritai visi gaminio parametrai (skaičiuojant kompozitinès grunto konstrukcijos armuotos geotinklais savybes) yra atitinkamai įvertinami su saugos koeficientais (Recommendations for..., 2011; Vaitkus ir kt., 2014). Projektavimo normose nurodyti saugos koeficientai nusako visas geotinklų savybes, kurios gali turèti ittakos bendrai kompozitinei grunto konstrukcijos laikomajai galiai bei nuosèdžiams eksploatuojant statini (Statybos techninis..., 2016; Šiukščius ir kt., 2016). Tokiu būdu skirtingos geotinklų savybès per visą eksploataciją užtikrina grunto kompozitinių konstrukcijų saugumą (1 pav.).
Per geotinklo gyvavimo ciklą (1 pav.) aiškiai matyti, kad skirtingose stadijose geotinklai elgiasi skirtingai, pasireiškia kitokios fizinès ir mechaninès savybès, ypač sandèliuojant, įrengimo ir apkrovimo laikotarpiu. Irengimo ir apkrovimo metu labai aktuali geotinklų prisitaikomumo prie esamos grunto konstrukcijos savybė (VIDEO: Huesker..., 2018) ir naudojant lanksčius geotinklus susidarantis arkos efektas virš įrengiamo geotinklo (Lackner ir kt., 2014).

Straipsnio tikslas - nustatyti standžiais ir lanksčiais geotinklais armuotų gruntų kerpamąji stiprị su triašio slègio aparatu. Šie tyrimai leidžia įvertinti standžiais ir lanksčiais geotinklais armuotų gruntų kompozitinių konstrukcijų privalumus ir trūkumus.

\section{EKSPERIMENTINIO BANDYMO APRAŠYMAS}

\section{Grunto užpildo savybès}

Tyrimai atlikti su Holoceno amžiaus jūrinių nuogulų (mIV) smèliniu gruntu, kurio pagrindinè sudètis yra kvarcas ( 85\%), žèrutis (6\%) ir kiti mineralai (Amšiejus ir kt., 2010), kietųjų dalelių tankis $\rho_{s}=2,65 \mathrm{~g} / \mathrm{cm}^{3}$ (Skuodis ir kt., 2017). Šio grunto dalelès pasižymi sferiškumu $\left(S_{2 D}=\right.$ 0,836), formos koeficientas $K_{f, 2 D}=0,702$ (Skuodis ir kt., 2014). Pagal granuliometrinę sudetį (2 pav.)

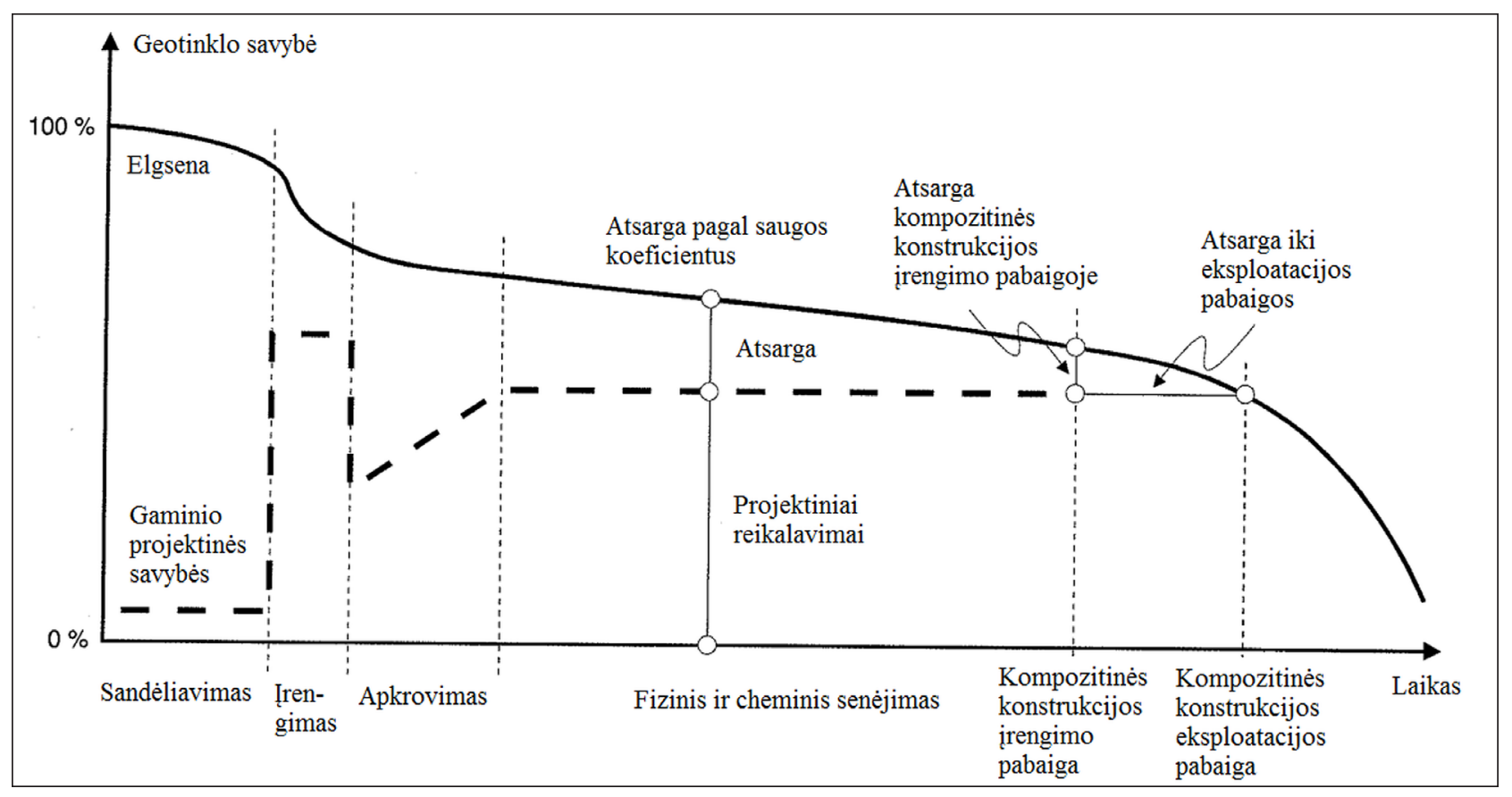

1 pav. Geotinklo gyvavimo ciklas (Rüegger, Hufenus, 2003)

Fig. 1. Life cycle of geogrid (Rüegger, Hufenus, 2003) 


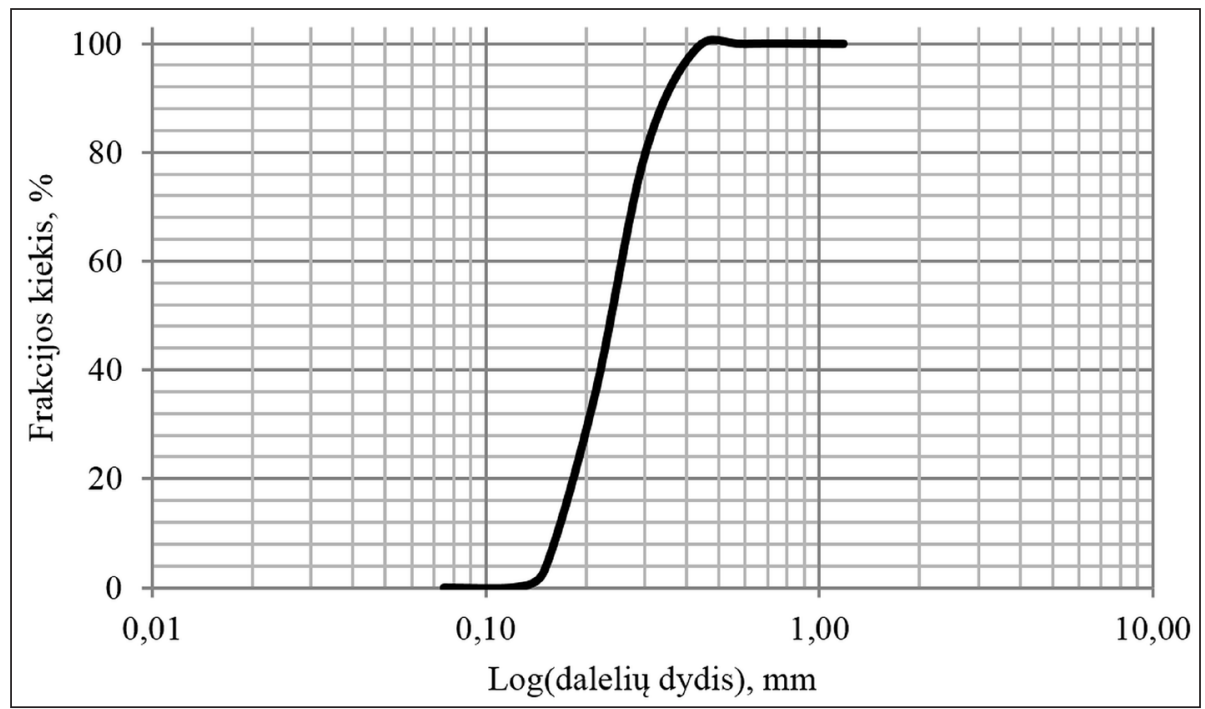

2 pav. Tirto grunto granuliometrinè sudètis

Fig. 2. Granulometric curve of investigated soil

nustatytas grunto pavadinimas - vidutinio rupumo smèlis (MSa) $\left(C_{U}=1,47 ; C_{C}=0,93\right.$; vienoda sankloda). Gruntą sudaro $1,34 \% \mathrm{rupi}, 96,38 \%$ vidutinio rupumo ir $2,28 \%$ smulki frakcija. Šis gruntas pasižymi vienoda dalelių forma (dalelès yra apvalios ir nugludintos bangų mūšos procesų), dydžiu, neturi dulkio ar molio bei žvyro frakcijų.

Dèl anksčiau išvardytų grunto savybių ji praktiškai galima vadinti etaloniniu gruntu taikomuosiuose moksliniuose tyrimuose. Etaloninius gruntus moksliniams tyrimams su biriais gruntais renkasi daugelis valstybių, pavyzdžiui: JAV naudoja Ottawa smèli, Nigerija - Igbokoda smèli, Korèja - Jumunjin smèlị, Kinija - Fujian smèlị (Ojuri, Agbolade, 2015; Skuodis ir kt., 2017).

$\mathrm{Su}$ šiuo gruntu atlikti geotinklais nearmuoto triašio slègio bandymai, kurie vèliau palyginti su geotinklais armuotų gruntų savybėmis. Bandymuose naudotas Baltijos jūros pakrantès smèlis (mIV) leidžia atskleisti tiriamų geotinklų armavimo savybes su mažiausia užpildo ịtaka gaunamiems rezultatams. Palyginimas atliktas vertinant armuoto / nearmuoto grunto santyki (Infante ir kt., 2016).

\section{Geotinklų savybès}

Armuotų kompozitinių grunto konstrukcijų tyrimų analizei panaudoti geotinklai, kurie yra vieni iš dažniausiai naudojamų Lietuvoje (Vaitkus ir kt., 2010). Palyginimui naudojami lankstūs
Basetrac $^{\circledast}$ Grid PP 40 ir Basetrac ${ }^{\circledast}$ Grid PET 40 bei standūs Secugrid 40/40 Q1 geotinklai. Norint užtikrinti palyginimo analizès skaidrumą, geotinklais armuotų kompozitinių grunto konstrukcijų rezultatai palyginti su nearmuoto grunto konstrukcijos rezultatais. Standžių ir lanksčių geotinklų savybés pateiktos 1 lentelèje.

\section{Triašio slègio bandymų metodika}

Bandymai atlikti su triašio slègio aparatu, kuriame tirti $100 \mathrm{~mm}$ skersmens ir $200 \mathrm{~mm}$ aukščio armuoto ir nearmuoto geotinklais grunto bandiniai. Pasirinktos bandymų sąlygos - izotropiniai konsoliduoti ir drenuoti bandymai (ISO/TS 17892-9:2004). Šios bandymų sąlygos atitinka realias automobilių kelių ir geležinkelių eksploatacines sąlygas. Bandyme naudotas grunto drègnis $W=6,00 \%$. Konsolidacijos trukmé - 30 min., pagal kurią apskaičiuotas vertikalių deformaciju greitis - 0,950\%/min. Per kiekvieną bandymą pasiekta didžiausia 15,00 \% vertikali bandinio deformacija, kad būtų galima nustatyti tiek pikines, tiek liekamąsias grunto stiprio reikšmes. Nearmuoti ir armuoti geotinklais grunto bandiniai ištirti esant celès slégiui $\sigma_{3}=100 ; 200$ ir $300 \mathrm{kPa}$.

Bandyme nearmuoto grunto geotinklais pradinis tankis $\rho=1,72-1,73 \mathrm{~g} / \mathrm{cm}^{3}$, armuoto grunto Basetrac ${ }^{\circledast}$ Grid PP $40-\rho=1,67-1,69 \mathrm{~g} / \mathrm{cm}^{3}$, armuoto grunto Secugrid 40/40 Q1 $-\rho=1,69-$ $1,70 \mathrm{~g} / \mathrm{cm}^{3}$ ir armuoto grunto Basetrac ${ }^{\oplus}$ Grid PET $40-\rho=1,69-1,72 \mathrm{~g} / \mathrm{cm}^{3}$. Pradiniai grunto 
1 lentelè. Pagrindinès lyginamųjų lanksčių ir standžių geotinklų savybės

Table 1. Main flexible and rigid geogrid properties

\begin{tabular}{|c|c|c|c|}
\hline $\begin{array}{l}\text { Savybės } \\
\text { Properties }\end{array}$ & $\begin{array}{c}\text { Basetrac }^{\circledast} \text { Grid } \\
\text { PP } 40\end{array}$ & $\begin{array}{l}\text { Secugrid } \\
40 / 40 \mathrm{Q} 1\end{array}$ & $\begin{array}{c}\text { Basetrac }^{\circledast} \text { Grid } \\
\text { PET } 40\end{array}$ \\
\hline Stipris tempiant išilgai & $\geq 40 \mathrm{kN} / \mathrm{m}$ & $\geq 40 \mathrm{kN} / \mathrm{m}$ & $\geq 40 \mathrm{kN} / \mathrm{m}$ \\
\hline Stipris tempiant skersai & $\geq 40 \mathrm{kN} / \mathrm{m}$ & $\geq 40 \mathrm{kN} / \mathrm{m}$ & $\geq 40 \mathrm{kN} / \mathrm{m}$ \\
\hline $\begin{array}{l}\text { Pailgejimas esant } \\
\text { didžiausiai apkrovai }\end{array}$ & $7 \%$ & $7 \%$ & $10 \%$ \\
\hline $\begin{array}{l}\text { Cheminio senèjimo } \\
\text { atsparumas }\end{array}$ & $\begin{array}{l}\text { Gaminys bus atsparus ne } \\
\text { mažiau kaip } 100 \text { metū, jei } \\
\text { jis naudojamas natūraliuo- } \\
\text { se gruntuose, kurių } 4<\mathrm{pH} \\
<9 \text { ir temperatūra }<25^{\circ} \mathrm{C}\end{array}$ & $\begin{array}{l}\text { Gaminys bus atsparus ne } \\
\text { mažiau kaip } 100 \text { metū, jei } \\
\text { jis naudojamas natūraliuo- } \\
\text { se gruntuose, kurių } 4<\mathrm{pH} \\
<9 \text { ir temperatūra }<25{ }^{\circ} \mathrm{C}\end{array}$ & $\begin{array}{l}\text { Gaminys bus atsparus ne } \\
\text { mažiau kaip } 100 \text { metų, jei } \\
\text { jis naudojamas natūraliuo- } \\
\text { se gruntuose, kurių } 4<\mathrm{pH} \\
<9 \text { ir temperatūra }<25^{\circ} \mathrm{C}\end{array}$ \\
\hline $\begin{array}{l}\text { Atmosferos poveikio } \\
\text { atsparumas }\end{array}$ & $\begin{array}{l}\text { Gaminys turi būti } \\
\text { uždengiamas per } 30 \text { dienų } \\
\text { nuo įrengimo }\end{array}$ & $\begin{array}{l}\text { Gaminys turi būti } \\
\text { uždengiamas per } 30 \text { dienų } \\
\text { nuo įrengimo }\end{array}$ & $\begin{array}{l}\text { Gaminys turi būti } \\
\text { uždengiamas per } 30 \text { dienų } \\
\text { nuo įrengimo }\end{array}$ \\
\hline
\end{tabular}

tankiai šiek tiek skiriasi, nes bandymuose naudotas vienas geotinklų armavimo sluoksnis per bandinio viduri ( 3 pav.), t. y. lygiai po $100 \mathrm{~mm}$ nuo bandinių apačios ir viršaus.

Didžiausią geotinklų armavimo efektą galima nustatyti armuojant grunto bandinius vienu geotinklų sluoksniu, t. y. per bandinio vidurị (Kamel ir kt., 2004). Dèl šios priežasties tyrimai su didesniu nei vienu armavimo sluoksniu bandinyje nebuvo atliekami.

\section{Duomenų interpretacija}

Atliekant bandymus su nearmuoto ir geotinklais armuoto grunto bandiniais, pikinès stiprio reikšmès nustatytos pagal didžiausią tangentinių ir normalinių ittempių santyki, t. y. $\tau / \sigma=\max$. Liekamosios stiprio reikšmès nustatytos pagal mažiausią tangentinių ir normalinių įtempių santyki, t. y. $\tau / \sigma=\min$.

Nearmuotų geotinklais grunto bandinių stipris kerpant išreiškiamas Moro-Kulono dèsniu

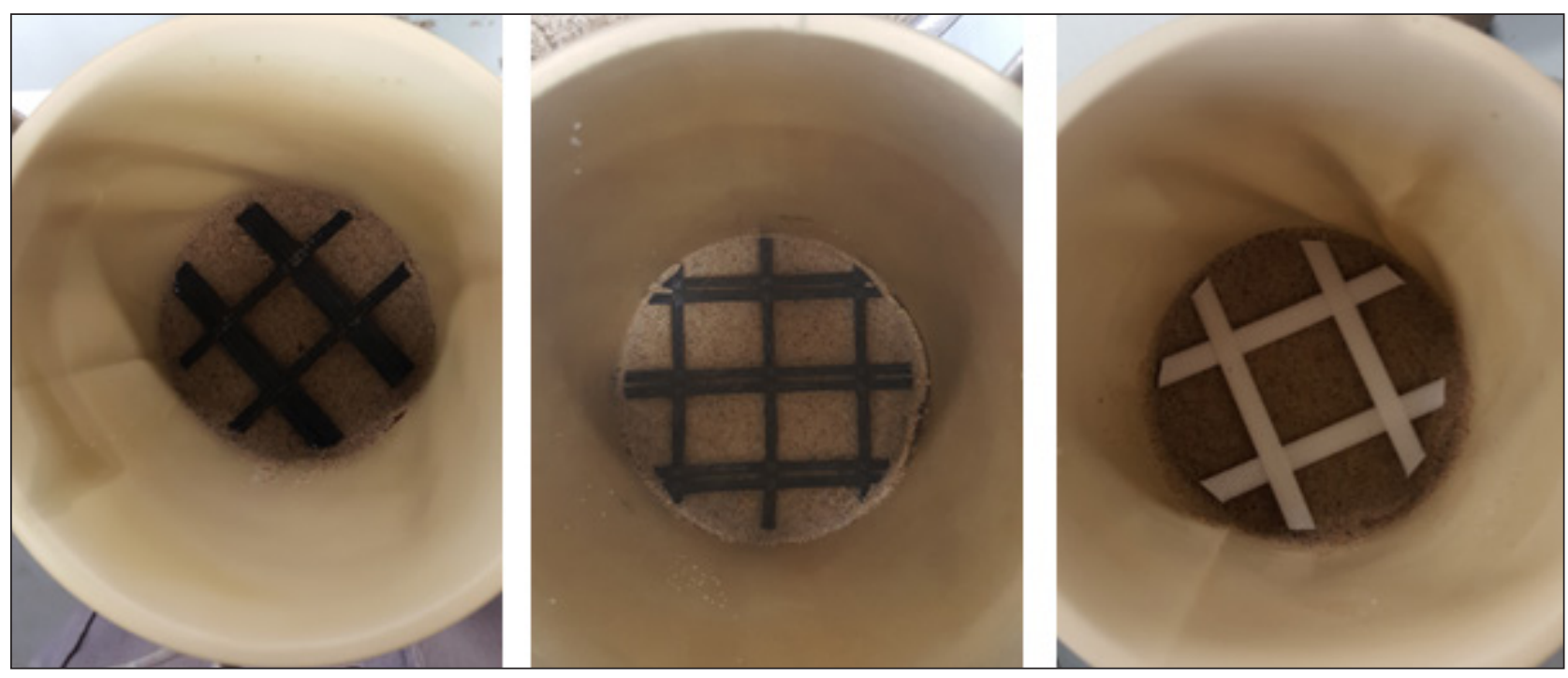

3 pav. Grunto bandinio armavimas geotinklais: kairëje - lankstus Basetrac ${ }^{\circledR}$ Grid PP 40 geotinklas; per viduri lankstus Basetrac ${ }^{\oplus}$ Grid PET 40 geotinklas; dešineje - standus Secugrid 40/40 Q1 geotinklas

Fig. 3. Sample reinforcement with geogrid: on the left hand side - flexible Basetrac ${ }^{\circledR}$ Grid PP 40 geogrid; in the middle - flexible Basetrac ${ }^{\circledast}$ Grid PET 40 geogrid; on the right hand side - rigid Secugrid 40/40 Q1 geogrid 
$\tau=\sigma \tan \phi+c$, kur vidinès trinties kampas ir sankiba nustatomi mažiausių kvadratų metodu (Dirgèliené, 2013). Geotinklais armuotų grunto bandinių vidinès trinties kampas ir sankiba vertinta pagal Moro-Kulono dèsnị, pritaikytą nustatyti geotinklų poveiki kerpamajam stipriui $\tau=$ $\sigma \tan \phi+c_{a}$. Žyméjimas $c_{a}$ reiškia tariamąją sankibą, kuri atsiranda bandant geotinklais armuotą gruntą (Infante ir kt., 2016).

\section{REZULTATU ANALIZE்}

Atlikus bandymus su nearmuoto geotinklais grunto bandiniais, nustatytas suirimo pobūdis (4 pav.), analogiškas pateikiamiems literatūroje (Tang ir kt., 2017; Wang ir kt., 2017; Yang, Pan 2017). Tačiau armuoto grunto geotinklais suirimo pobūdis skiriasi nuo nearmuoto (5 pav.).

Analizuojant nearmuoto grunto suirimo schemą (4 pav.) aiškiai matyti, kad gruntas suyra per visą bandinio aukštị, o suirimo kampas priklauso nuo grunto vidinès trinties kampo. Tokia suirimo schema negalioja grunto kompozitineje konstrukcijoje, armuotoje geotinklais (5 pav.). Tiek

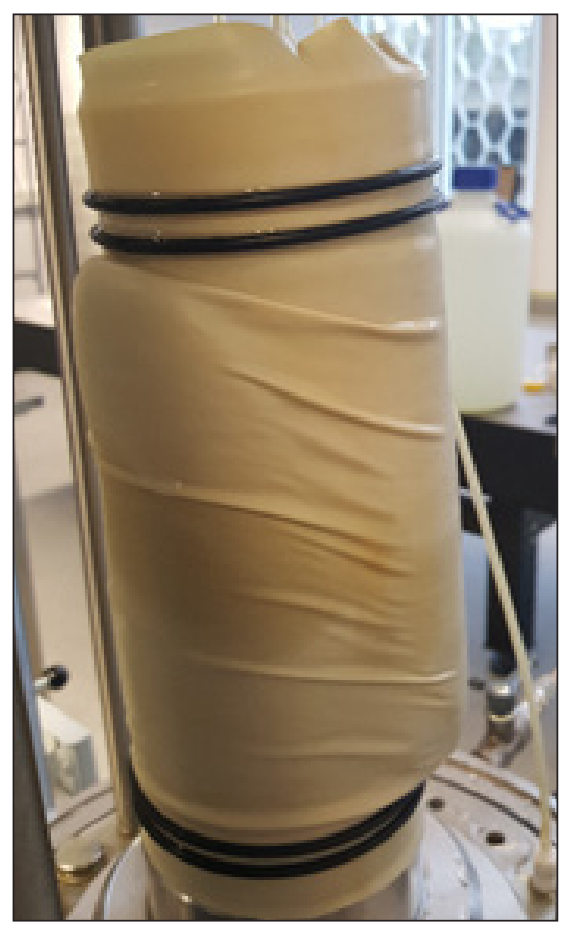

4 pav. Suardyto grunto, nearmuoto geotinklais, suirimo pobūdis

Fig. 4. Failure shape of unreinforced soil lanksčiais, tiek standžiais geotinklais armuotų grunto bandinių suirimo pobūdis pasižymi iki 10 irimo plokštumų susidarymu, kurios tęsiasi iki bandinio vidurio, t. y. iki geotinklo.

Nepaisant to, kad grunto bandiniai suyra virš irrengto geotinklo, per bandymą nustatyti ịtempiu deviatoriai $\left(\sigma_{D}\right)$ gaunami daug didesni nei nearmuotų geotinklais. Detalus ịtempių deviatorių nuo vertikalių deformacijų palyginimas yra pateiktas atskirai, kai bandymų metu celès slègiai yra skirtingi (6-8 pav.).

Analizuojant apibendrintus rezultatus, pateiktus 6-8 pav., matyti, kad tiek lanksčių, tiek standžių geotinklų naudojimas grunto kompozitinèse konstrukcijose leidžia pasiekti geresnių rezultatų, palyginti su nearmuoto grunto rezultatais. Vieninteliu atveju, kai celès slègis yra $300 \mathrm{kPa}$, nearmuoto grunto pikinis stipris panašus i armuoto grunto (tiek su lanksčiu, tiek su standžiu geotinklu), nes dèl didelio celès slègio pasikeičia ịtempių būvis bandomame bandinyje (Medzvieckas ir kt., 2017). Tačiau nukirptas bandinys, kuris yra toliau kerpamas ir tiriamas liekamasis stipris, net kai celès slègis siekia $300 \mathrm{kPa}$, nearmuoto grunto bandiniai negali lygintis su armuoto grunto lanksčių ir standžių geotinklų rezultatais.

Gauti rezultatai (6-8 pav.) atskleidè, kad lankstūs geotinklai Basetrac ${ }^{\oplus}$ Grid PP 40 ir Ba$\operatorname{setrac}^{\oplus}$ Grid PET 40 yra lygiaverčiai gaminiai ir nẻ kiek nenusileidžia savo armuojančiomis savybėmis standžiam Secugrid 40/40 Q1 geotinklui. Bandymais nustatyta, kad šiek tiek geresni rezultatai gaunami armuojant gruntą Basetrac ${ }^{\circledR}$ Grid PET 40 geotinklu, palyginti su Secugrid 40/40 Q1 geotinklo nustatytais rezultatais. Šis efektas yra paaiškinamas didesniu akučių kiekiu tokiame pačiame plote, t. y. Basetrac ${ }^{\circledast}$ Grid PET 40 geotinklas turi keturias akutes, o Secugrid 40/40 Q1 geotinklas - vieną akutę ( 3 pav.). Išsami palyginamoji kerpamojo stiprio rezultatų analizè pateikta 2 lenteleje.

Lyginant bandiniu pikinio stiprio rezultatus, pateiktus 2 lentelèje, pastebima, kad nearmuoto grunto bandiniai nusikerpa ties praktiškai dvigubai mažesne vertikalia deformacija (kai celès slègis $100,200 \mathrm{kPa}$ ), nei grunto bandiniai, armuoti geotinklais. Analizuojant lanksčių ir standžių geotinklų kerpamuosius stiprius nustatyta, kad lanksčiu geotinklu armuotas gruntas pikini 

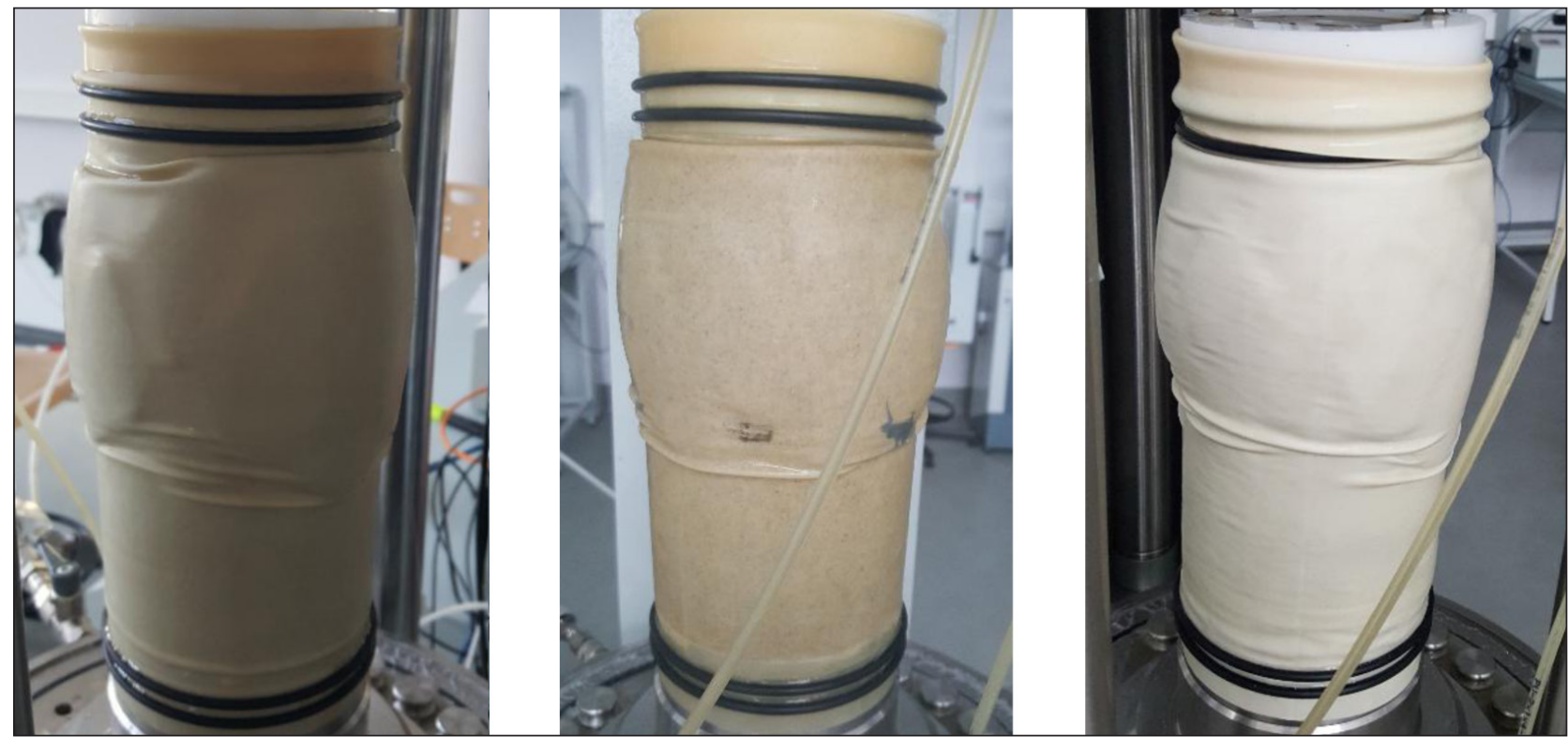

5 pav. Bandinių suirimo pobūdis: kaireje - armuota Basetrac ${ }^{\circledR}$ Grid PP 40 geotinklu; viduryje - armuota Basetrac ${ }^{\circledR}$ Grid PET 40 geotinklu; dešinejje - armuota Secugrid 40/40 Q1 geotinklu

Fig. 5. Failure shape of reinforced soil with geogrid: on the left hand side - reinforced with Basetrac ${ }^{\circ}$ Grid PP 40 geogrid; in the middle - reinforced with Basetrac ${ }^{\circledR}$ Grid PET 40 geogrid; on the right hand side - reinforced with Secugrid 40/40 Q1 geogrid

stiprị pasiekia išsivysčius didesnèms vertikalioms deformacijoms, nei standžiu geotinklu armuoto grunto. Tai yra labai gera savybè, nes projektuojant grunto kompozitines konstrukcijas, armuo- tas lanksčiais geotinklais, galima numatyti didesnes konstrukcijos deformacijas ir žinoti, kad konstrukcija nesuirs (nepasieks pikinio stiprio). Kitaip yra su standžiais geotinklais.

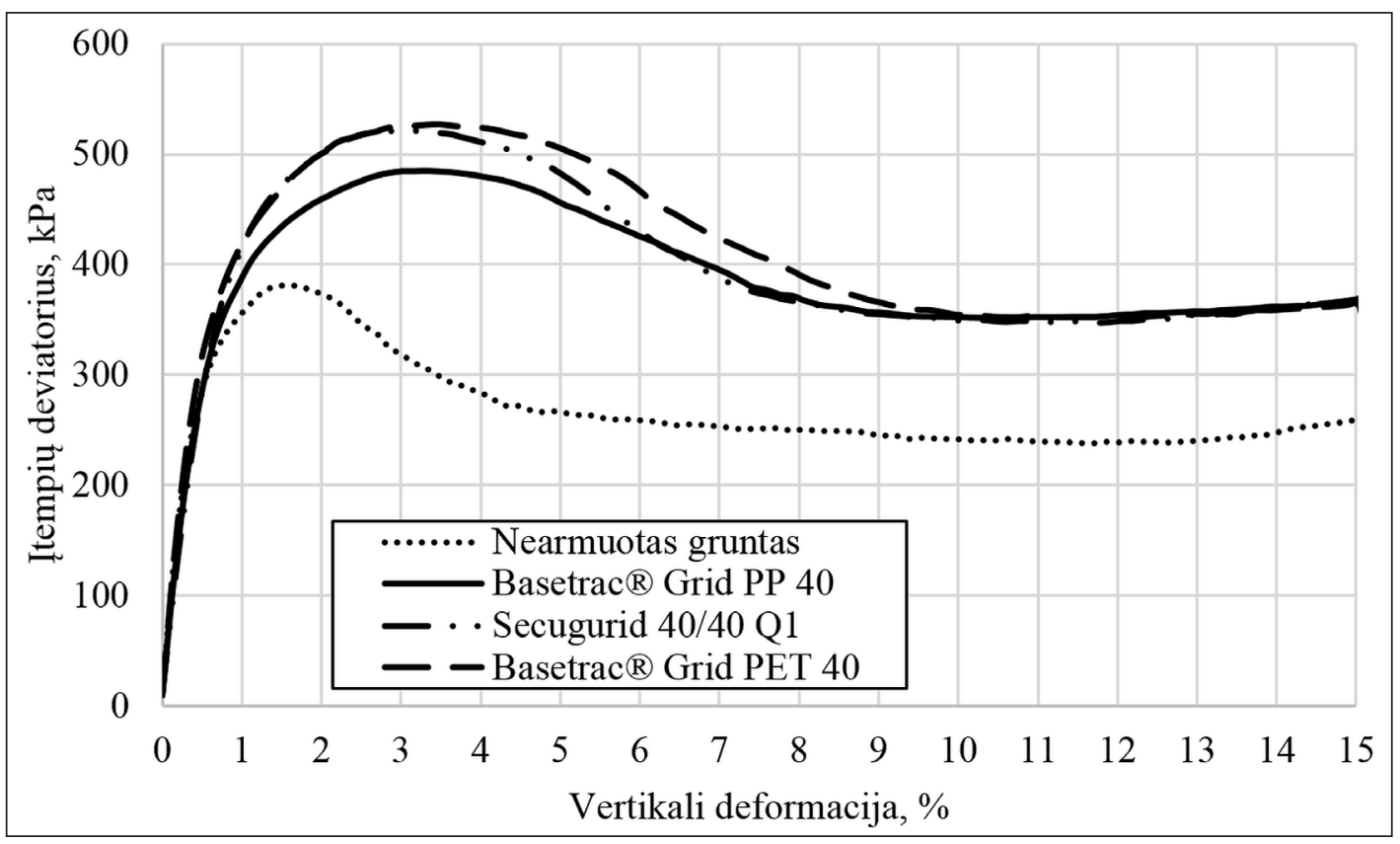

6 pav. Nearmuoto ir armuoto geotinklais grunto įtempių deviatorių ir vertikalių deformacijų priklausomybiu palyginimas, kai celès slègis $\sigma_{3}=100 \mathrm{kPa}$

Fig. 6. Unreinforced and reinforced soil with geogrids deviator change versus vertical strain, when cell pressure $\sigma_{3}=100 \mathrm{kPa}$ 


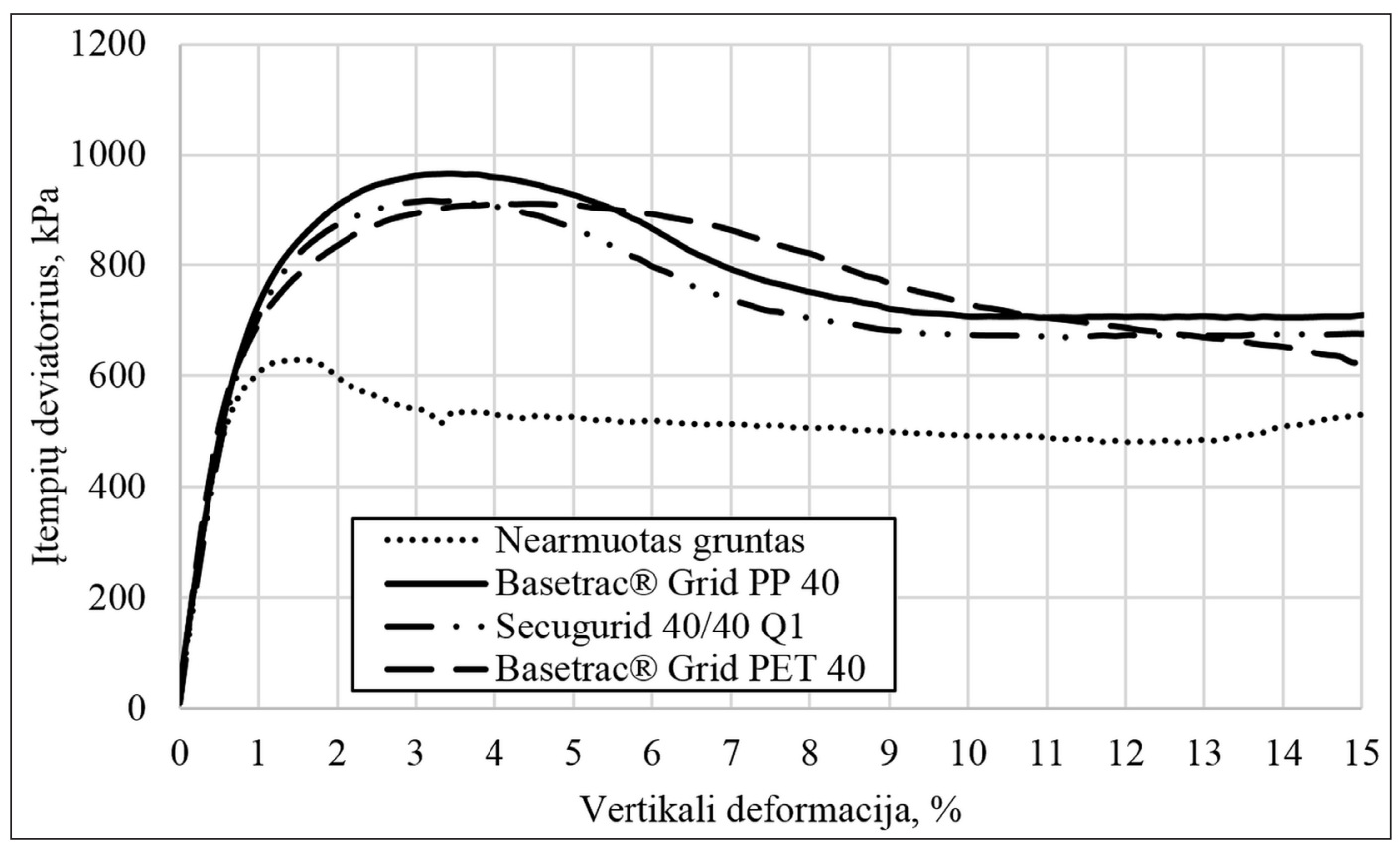

7 pav. Nearmuoto ir armuoto geotinklais grunto ittempių deviatorių ir vertikalių deformacijų priklausomybių palyginimas, kai celès slègis $\sigma_{3}=200 \mathrm{kPa}$

Fig. 7. Unreinforced and reinforced soil with geogrids deviator change versus vertical strain, when cell pressure $\sigma_{3}=200 \mathrm{kPa}$

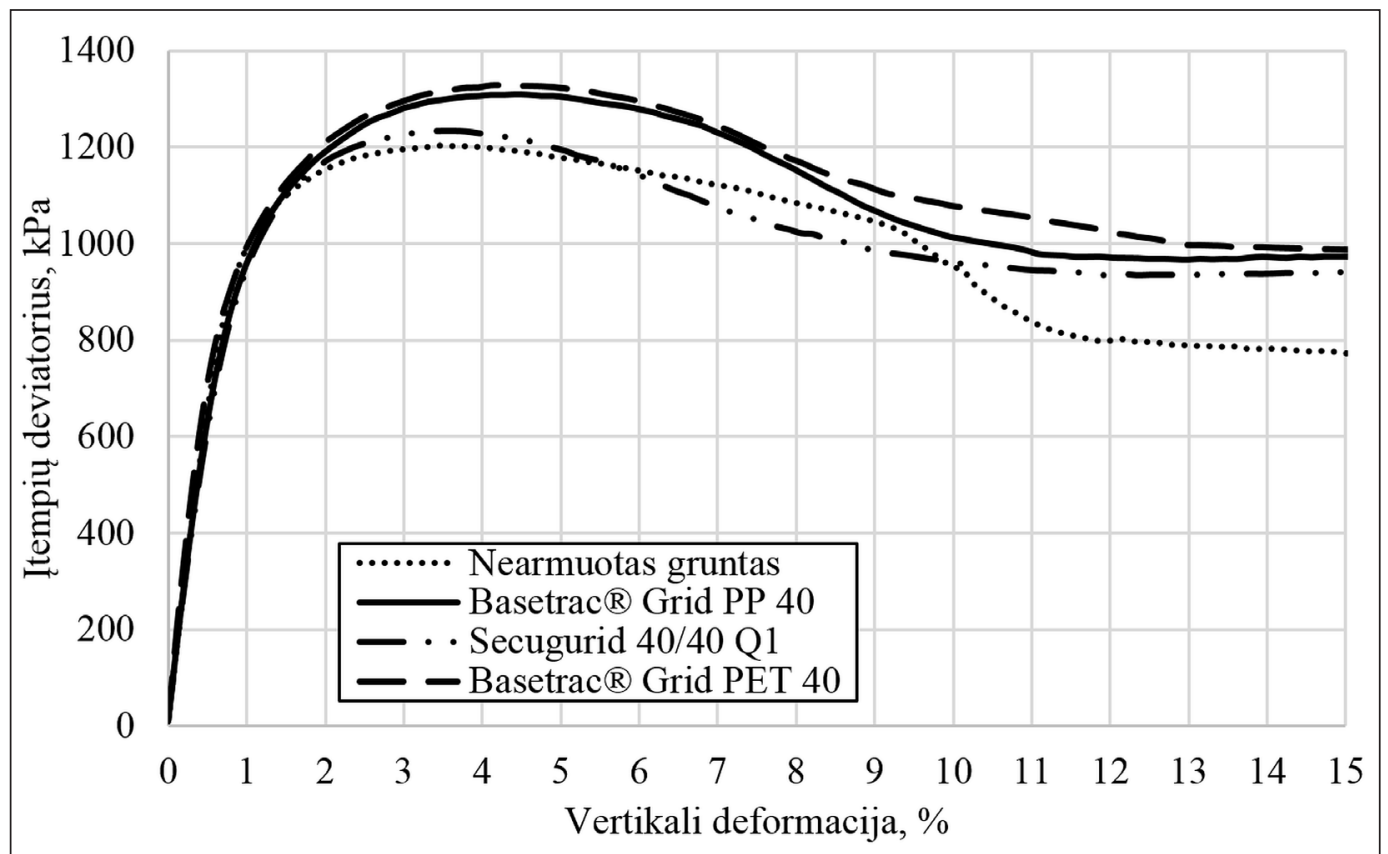

8 pav. Nearmuoto ir armuoto geotinklais grunto ịtempių deviatorių ir vertikalių deformacijų priklausomybių palyginimas, kai celès slègis $\sigma_{3}=300 \mathrm{kPa}$

Fig. 8. Unreinforced and reinforced soil with geogrids deviator change versus vertical strain, when cell pressure $\sigma_{3}=300 \mathrm{kPa}$

Pažymètina, kad grunto sankiba kompozitinèje grunto konstrukcijoje nèra tikroji grunto sankiba. Geotinklais armuoto grunto atveju, sankibą re- komenduojama vertinti pagal Infante (2016), t. y. sankibą traktuoti kaip kompozitinès konstrukcijos elgsenos parametrą, kuris biriems gruntams 
2. le ntelè. Nearmuoto ir armuoto geotinklais grunto kerpamasis stipris

Table 2. Unreinforced and reinforced soil with geogrid shearing strength

\begin{tabular}{|c|c|c|c|c|c|c|}
\hline \multicolumn{7}{|c|}{ Pikinis stipris / Peak strength } \\
\hline $\begin{array}{l}\text { Bandymo } \\
\text { sąlygos } \\
\text { Test condi- } \\
\text { tions }\end{array}$ & $\begin{array}{c}\text { Celès } \\
\text { slègis } \\
\text { Cell pres- } \\
\text { sure } \\
\sigma_{3}, \mathrm{kPa}\end{array}$ & $\begin{array}{l}\text { Itempių } \\
\text { deviatorius } \\
\text { Deviator } \\
\sigma_{D}, \mathrm{kPa}\end{array}$ & $\begin{array}{l}\text { Vertikali } \\
\text { deformacija } \\
\text { Vertical } \\
\text { strain } \\
\varepsilon, \%\end{array}$ & $\begin{array}{l}\text { Vidinès trin- } \\
\text { ties kampas } \\
\text { Angle of } \\
\text { internal fric- } \\
\text { tion } \phi_{m, f}^{c}\end{array}$ & $\begin{array}{c}\text { Sankiba } \\
\text { Cohesion } \\
c_{m, p} \mathrm{kPa}\end{array}$ & $\begin{array}{l}\text { Kerpamojo stiprio santykis } \\
\text { (armuota / nearmuota) } \\
\text { Shearing strength ratio (re- } \\
\text { inforced/unreinforc-ed) }\end{array}$ \\
\hline \multirow{3}{*}{ Nearmuota } & 104,54 & 380,67 & 1,5810 & \multirow{3}{*}{40,77} & \multirow{3}{*}{0,00} & - \\
\hline & 202,98 & 627,85 & 1,5758 & & & - \\
\hline & 305,39 & 1202,45 & 3,4799 & & & - \\
\hline \multirow{3}{*}{$\begin{array}{l}\text { Armuota } \\
\text { Basetrac }^{\circledast} \\
\text { Grid PP } 40\end{array}$} & 106,68 & 484,87 & 3,3234 & \multirow{3}{*}{42,28} & \multirow{3}{*}{22,82} & 1,31 \\
\hline & 204,78 & 966,78 & 3,4615 & & & 1,31 \\
\hline & 305,30 & 1308,82 & 4,4283 & & & 1,12 \\
\hline \multirow{3}{*}{$\begin{array}{l}\text { Armuota } \\
\text { Secugrid } \\
40 / 40 \text { Q1 }\end{array}$} & 106,20 & 521,38 & 3,0033 & \multirow{3}{*}{39,78} & \multirow{3}{*}{43,47} & 1,43 \\
\hline & 205,65 & 916,87 & 3,3232 & & & 1,31 \\
\hline & 305,13 & 1233,04 & 3,6346 & & & 1,09 \\
\hline \multirow{3}{*}{$\begin{array}{c}\text { Armuota } \\
\text { Basetrac }^{\circledR} \\
\text { Grid PET } 40\end{array}$} & 107,01 & 526,76 & 3,3171 & \multirow{3}{*}{41,90} & \multirow{3}{*}{20,27} & 1,32 \\
\hline & 206,10 & 1114,53 & 5,0638 & & & 1,27 \\
\hline & 306,44 & 1635,05 & 4,1152 & & & 1,11 \\
\hline \multicolumn{7}{|c|}{ Liekamasis stipris / Residual strength } \\
\hline $\begin{array}{l}\text { Bandymo } \\
\text { sąlygos } \\
\text { Test condi- } \\
\quad \text { tions }\end{array}$ & $\begin{array}{l}\text { Celès } \\
\text { slègis } \\
\text { Cell pres- } \\
\text { sure } \\
\sigma_{3}, \mathrm{kPa}\end{array}$ & $\begin{array}{l}\text { Itempių } \\
\text { deviatorius } \\
\text { Deviator } \\
\sigma_{D}, \mathrm{kPa}\end{array}$ & $\begin{array}{c}\text { Vertikali } \\
\text { deformacija } \\
\text { Vertical } \\
\text { strain } \\
\varepsilon, \%\end{array}$ & $\begin{array}{l}\text { Vidinès trin- } \\
\text { ties kampas } \\
\text { Angle of } \\
\text { internal fric- } \\
\text { tion } \phi_{m, f}^{c}\end{array}$ & $\begin{array}{c}\text { Sankiba } \\
\text { Cohesion } \\
c_{m, p} \mathrm{kPa}\end{array}$ & $\begin{array}{l}\text { Kerpamojo stiprio santykis } \\
\text { (armuota / nearmuota) } \\
\text { Shearing strength ratio (re- } \\
\text { inforced/unreinforc-ed) }\end{array}$ \\
\hline \multirow{3}{*}{ Nearmuota } & 100,36 & 237,99 & 11,5560 & \multirow{3}{*}{33,82} & \multirow{3}{*}{0,00} & - \\
\hline & 200,42 & 480,12 & 12,3425 & & & - \\
\hline & 300,54 & 771,10 & 15,0383 & & & - \\
\hline \multirow{3}{*}{$\begin{array}{l}\text { Armuota } \\
\text { Basetrac }^{\circledR} \\
\text { Grid PP } 40\end{array}$} & 103,20 & 350,68 & 10,7681 & \multirow{3}{*}{37,26} & \multirow{3}{*}{15,43} & 1,49 \\
\hline & 199,08 & 707,15 & 12,4866 & & & 1,39 \\
\hline & 301,42 & 966,10 & 12,9783 & & & 1,29 \\
\hline \multirow{3}{*}{$\begin{array}{l}\text { Armuota } \\
\text { Secugrid } \\
40 / 40 \text { Q1 }\end{array}$} & 102,23 & 347,11 & 11,7116 & \multirow{3}{*}{36,39} & \multirow{3}{*}{17,17} & 1,45 \\
\hline & 202,81 & 669,34 & 11,0815 & & & 1,34 \\
\hline & 298,56 & 934,24 & 13,0695 & & & 1,23 \\
\hline \multirow{3}{*}{$\begin{array}{c}\text { Armuota } \\
\text { Basetrac }^{\circledast} \\
\text { Grid PET } 40\end{array}$} & 102,43 & 454,79 & 11,5504 & \multirow{3}{*}{38,07} & \multirow{3}{*}{1,33} & 1,31 \\
\hline & 201,92 & 821,89 & 14,9011 & & & 1,23 \\
\hline & 301,38 & 1293,53 & 13,6201 & & & 1,22 \\
\hline
\end{tabular}

gali būti santykinai didelis, palyginti su nearmuotų birių gruntų sankibos vertèmis (Kamel, 2004). Net ir mažas vidinès trinties kampo pokytis vienu laipsniu turi didesnę įtaką bendram kerpamajam stipriui, palyginti su sankibos reikšmių padidejjimu nuo 0 iki $40 \mathrm{kPa}$ (Skuodis ir kt., 2016). 


\section{IŠVADOS}

Apibendrinant lanksčių ir standžių geotinklų grunto armavimo ittaką galima suformuluoti tokias išvadas:

1. Geotinklų naudojimas armuojant grunto kompozitines konstrukcijas pagerina jų savybes, palyginti su nearmuotomis.

2. Analizuojant lanksčių ir standžiu geotinklų kerpamuosius stiprius nustatyta, kad lanksčiu geotinklu armuotas gruntas pikinị stiprị pasiekia išsivysčius didesnėms vertikalioms deformacijoms, nei grunto, armuoto standžiu geotinklu.

3. Armuotos kompozitinès konstrukcijos vidinès trinties kampo pikinès reikšmès kinta nežymiai (nuo $39,78^{\circ}$ iki $42,28^{\circ}$ ), palyginti su nearmuotos $\left(40,77^{\circ}\right)$. Liekamosios reikšmès kinta intervale nuo $33,82^{\circ}$ (nearmuotas gruntas) iki $38,07^{\circ}$ (armuotas gruntas). Armuoto grunto atveju pikinè tariamoji sankiba padideja iki $43,47 \mathrm{kPa}$, liekamoji - iki 17,17 kPa.

4. Armuoto / nearmuoto grunto kerpamojo stiprio santykis padidèja nuo 1,09 iki 1,49 . Mažesnès reikšmès gaunamos esant pikinėms kerpamojo stiprio reikšmèms ir didesniam celès slègiui.

5. Bandant triašio slègio aparatu paaiškejo, kad pagal gautus rezultatus lankstūs Basetrac ${ }^{\oplus}$ Grid PP 40 ir Basetrac ${ }^{\oplus}$ Grid PET 40 geotinklai yra lygiaverčiai gaminiai ir nẻ kiek nenusileidžia savo armuojančiomis savybèmis, palyginti su standžiu Secugrid 40/40 Q1 geotinklu.

\section{PADE்KA}

Šių tyrimų autoriai yra dèkingi Vilniaus Gedimino technikos universiteto Civilinès inžinerijos mokslo centrui už suteiktą tyrimų bazę ir bandymuose naudotas medžiagas.

Gauta 20180108

Priimta 20180401

\section{LITERATŪRA}

1. Amšiejus J., Kačianauskas R., Norkus A., Tumonis L. 2010. Investigation of the sand porosity via oedometer testing. The Baltic Journal of Road and Bridge Engineering. 5(3): 139-147.

2. Dirgèlienė N. 2013. Grunto tyrimas triašio slègio aparatu. Vilnius: Technika. 43 p.
3. Dèl geosintetikos naudojimo žemès darbams keliuose metodiniu nurodymu MN GEOSINT ŽD 13 patvirtinimo. Lietuvos automobilių kelių direkcijos prie Susisiekimo ministerijos direktoriaus isakymas. $2013 \mathrm{~m}$. kovo $22 \mathrm{~d}$. Nr. V-122.

4. Infante D. J. U., Martinez G. M. A., Arrua P. A., Eberhardt M. 2016. Shear strength behavior of different geosynthetic reinforced soil structure from direct shear test. International Journal of Geosynthetics and Ground Engineering. 2(17): $1-17$.

5. ISO/TS 17892-9:2004. Geotechnical investigation and testing. Laboratory testing of soil. Part 9: Consolidated triaxial compression tests on watersaturated soils.

6. Kamel M. A., Chandra S., Kumar P. 2004. Behaviour of subgrade soil reinforced with geogrgid. International Journal of Pavement Engineering. 5(4): 201-209.

7. Lackner C., Marte R., Bergado D. T., Semprich S. 2014. Prestressed reinforced soil for infrastructure projects - a microscopic research. XV DanubeEuropean Conference on Geotechnical Engineering (DECGE 2014). Vienna, Austria. Paper No. 67.

8. Medzvieckas J., Dirgèlienė N., Skuodis Š. 2017. Stress-strain states differences in specimens during triaxial compression and direct shear tests. Procedia Engineering. Modern Building Materials, Structures and Techniques, MBMST 2016. Amsterdam: Elsevier Ltd. 172(2017): 739-745.

9. Ojuri O. O., Agbolade O. C. 2015. Improvement of engineering properties of Igbokoda standard sand with shredded polyethylene wastes. Nigeria Journal of Technology. 34(3): 443-451.

10. Recommendations for design and analysis of earth structures using geosynthetic reinforcements EBGEO, Translation of the 2nd German Edition, Published by the German Geotechnical Society (Deutsche Gesellschaft Für Geotechnik e.V., DGGT), 2011.

11. Rüegger R., Hufenus R. 2003. Bauen mit Geokunststoffen: ein Handbuch für den GeokunststoffAnwender. SVG [in German].

12. Skuodis Š., Karaman A. H., Dirgèlienè N. 2017. Comparison of one-step and step-wise compression tests. Geologija. Geografija. 3(1): 1-10.

13. Skuodis Š., Markauskas D., Norkus A., Žaržojus G., Dirgèliené N. 2014. Testing and numerical simulation of Holocene marine sand uniaxial compression at Lithuanian coast. Baltica. 27(1): 33-44.

14. Skuodis Š., Norkus A., Dirgèlienè N., Rimkus L. 2016. Determining characteristic sand shear parameters of strength via a direct shear test. Journal of Civil Engineering and Management. 22(2): 271-278.

15. Statybos techninis reglamentas STR 2.05.21:2016 Geotechninis projektavimas. Bendrieji reikalavimai, patvirtintas $2016 \mathrm{~m}$. liepos $4 \mathrm{~d}$. (issakymo Nr. D1-468). 
16. Šiukščius A., Vorobjovas V., Vaitkus A. 2017. Geogrid reinforced subgrade influence to ensure paved road durability. 10th International Conference "Environmental Engineering". Vilnius Gediminas Technical University, Lithuania. Vilnius: VGTU Press 2017, 1-7.

17. Tang H., Zhang X., Ji S. 2017. Discrete element analysis for shear band modes of granular materials in triaxial tests. Particulate Science and Technology. 35(3): 277-290.

18. Vaitkus A., Čygas D., Laurinavičius A. 2010. Use of geosynthetics for the strengthening of road pavement structure in Lithuania. Geosynthetics for a challenging world: 9th International Conference on Geosynthetics, Guaruja, Brazil. Vol. 3. San Paulo: Brazilian Chapter of the International Geosynthetics Society (IGS-Brazil), 1575-1580.

19. Vaitkus A., Šiukščius A., Ramūnas V. Regulations for use of geosynthetics for road embankments and subgrades. The Baltic Journal of Road and Bridge Engineering. (9)2: 88-93.

20. VIDEO: Huesker explains "Interaction flexibility". http://www.worldhighways.com/categories/asphalt-paving-compaction-testing/features/videohuesker-explains-interaction-flexibility/ (žiūrèta $20180105)$.

21. Wang H., Koseki J., Sato T. 2017. p-Constant Condition Applied to Undrained Cyclic Triaxial Test of Unsaturated Soils. Geotechnical Testing Journal. 40(4): 710-718.

22. Yang Z. X., Pan K. 2017. Flow deformation and cyclic resistance of saturated loose sand considering initial static shear effect. Soil Dynamics and Earthquake Engineering. 92: 68-78.
Šarūnas Skuodis, Neringa Dirgèlienè

\section{INVESTIGATION OF SOIL SHEARING STRENGTH REINFORCED WITH GEOGRID}

Sum mary

This paper presents the results of a static triaxial test on soil samples reinforced with geogrid, conducted with the aim to characterize the shear strength of reinforced soil composite. To reach the aim it was chosen to provide triaxial tests without geogrid reinforcement and to compare later obtained results with soil samples reinforced with geogrid. Two types of flexible geogrid and one type of rigid geogrid were selected with ultimate tensile strength $\geq 40 \mathrm{kN} / \mathrm{m}$. Laboratory testing programs were performed with a static triaxial test device, where sample diameter was $100 \mathrm{~mm}$ and height was $200 \mathrm{~mm}$. The samples were made with initial water content of $6.00 \%$ and average density varying from 1.67 to $1.73 \mathrm{~g} / \mathrm{cm}^{3}$ (according to different geogrid reinforcement type). The reinforcement layer was placed directly in the middle of the samples and all triaxial tests were conducted according to isotropic, unsaturated, consolidated and drained conditions with three confining cell pressures: 100, 200 and $300 \mathrm{kPa}$. During the loading stage, there was used a $0.950 \% /$ min vertical strain ramp, until maximum deformation of $15.0 \%$ was reached. The effect of different geogrid reinforcement on shearing strength results was analyzed, mainly peak and residual shearing strength. The tests results revealed that the shearing strength increases if soil sample is reinforced with geogrid. Using flexible geogrids, the maximum peak shearing strength was reached at higher vertical strains when compared with a rigid geogrid. In general, the improvement of shearing strength is obtained with soil samples reinforced with flexible and rigid geogrids compared to samples without reinforcement. In this study, flexible and rigid geogrids used for experimental testing are equivalent products, which can be successfully applied for Lithuanian roads and railways structures.

Keywords: geogrid, shearing strength, angle of internal friction, cohesion 